
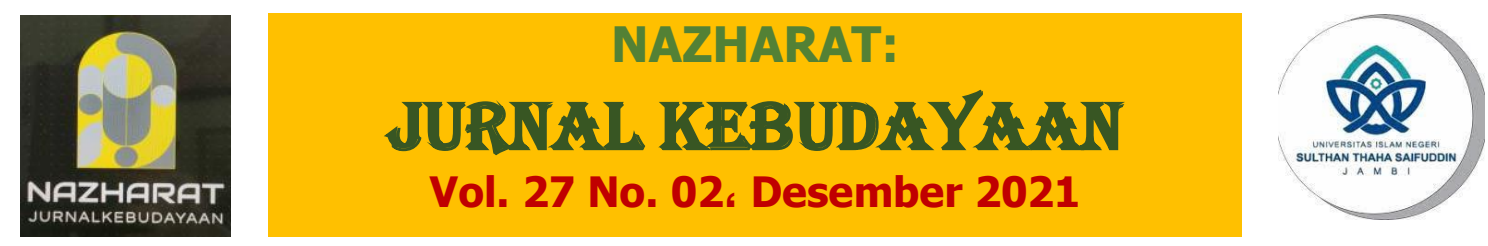

\title{
SISTEM PENGOBATAN TRADISONAL BEGIJOL PADA SUKU ANAK DALAM DI JAMBI
}

\author{
Mailinar,Mardiyanti,Aliyas \\ UIN Sulthan Thaha Saifuddin Jambi \\ mailinar@uinjambi.ac.id
}

\begin{abstract}
Artikel ini mendeskripsikan tentang Sistem pengobatan tradisional Begijol pada komunitas adat terpencil suku anak dalam di desa Bungku. Penelitian ini menggunakan pendekatan etnografi, dimana penentuan informan dilakukan dengan teknik purposive sampling. Sistem Peogobatan Tradisional Begijol merupakan sistem pengobatan yang berbentuk ritual dan mantera, menggunakan herbal atau bahan bahan alami yang terdapat dimasyarakat seperti sirih, kelapa umbut padi, gambir, arang, pinang dan lain lain. Jenis obat yang digunakan tergantung dengan jenis penyakit. Tradisi pengobatan ini tidak bisa lepas dari Suku Anak Dalam yang berdomisili di desa Bungku. Sistem pengobatan tradisional ini bertahan dan masih dilaksanakan oleh suku anak dalam karena sistem pengobatan tradisional ini merupakan warisan leluhur dari nenek moyang suku anak dalam, kekecewaan terhadap tenaga medis dan rendahnya pemahaman agama juga menjadi faktor tradisi ini bertahan.
\end{abstract}

Keywords : Pengobatan, Tradisional, Suku Anak Dalam

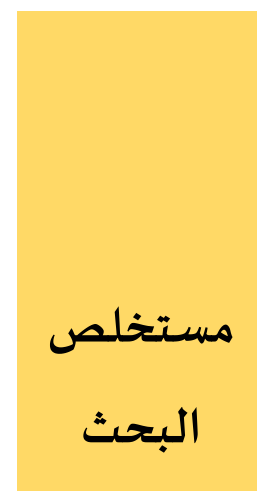

Abstract
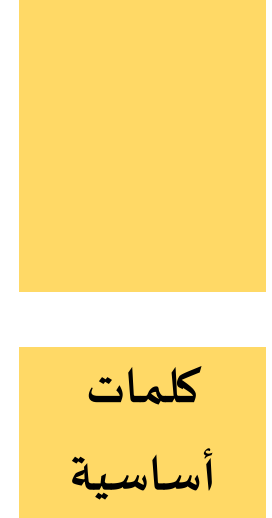

Keyword

\section{INTRODUCTION (مقدمة)}

Konsep sakit dan penyakit merupakn dua hal yang berbeda, penyakit (disease) diartikan sebagai gangguan fungsi fisiologis dari suatu organism sebagai akibat dari infeksi atau tekanan dari lingkungan, dan sakit (illness) merupakan penilaian individu terhadap pengalaman menderita suatu penyakit (Sarwono, 1993:31). Konsep atau istilah penyakit bersifat objektif, sedangkan sakit lebih subjektif. Sehingga mungkin saja terjadi secara objektif seseorang tersebut terserang penyakit, dan menjalankan tugasnya sehari-hari karena merasa dirinya tidak sakit. Sebaliknya, 
seseorang mungkin merasa sakit namun secara medis tidak diperoleh bukti bahwa dirinya terserang penyakit.

Rasa sakit yang dialami seseorang tentunya membutuhkan sistem pengobatan. Sistem pengobatan tidak bisa dipisahkan dari sistem pengetahuan manusia yang bersifat tradisional ataupun modern. Sistem pengobatan tradisional merupakan pengobatan yang dilakukan secara turun temurun yang digunakan oleh suku-suku bangsa tertentu untuk mengatasi masalah kesehatan. Pengobatan tradisional biasanya dilakukan Dukun, Malim, Sidi, Inang, Sando Mbu'owai, Sando Pe'ana, Mbo'Pui, dan Sibaso.(Dloyanah Kusumah, 2017: 3).

Sistem Pengobatan tradisional membutuhkan ritual sebagai salah satu proses yang dilakukan dalam melakukan penyembuhan terhadap rasa sakit yang dialami oleh setiap masyarakat yang berkaitan erat dengan sistem kepercayaan dengan menggunakan ilmu magic ( Uniawati:2012:2). Sistem pengobatan tradisional yang menggunakan konsep seperti ini disebut dengan sistem "Traditional Medicine"atau yang disebut dengan sistem pengobatan dukun. Sistem pengobatan ini tidak bisa dipisahkan dari kehidupan masyarakat tradisional dan suku-suku bangsa, seperti pengobatan tradisional yang ada di masyarakat Bugis-Makasar( Dloyanah Kusumah, 2017:5). Peranan Sando/dukun pada sistem pengobatan tradisional masyarakat Onembute, masyarakat Onembute mengenal tiga macam sando/dukun, yaitu Mbu'owai, Sando Pe'ana, dan Mbo'Pui. Yang mempunyai peran yang berbeda- beda dalam sistem pemgobatan tradisional masyarakat Onembute, sando/dukun Mbu'owai memiliki peranan untuk menyembuhkan segala jenis penyakit. Sando/dukun Pe'ana memiliki peranan dalam menangani persalinan dan sando/dukun Mbu'Pui memiliki peranan dalam mengobati patah tulang (Tini Suryaningsi,2015:485)

Jambi sebagai representasi masyarakat yang majemuk suku bangsanya, sampai hari ini masih melakukan dan mempertahankan sistem pengobatan tradisional sebagai salah satu alternatif dalam sistem penyembuhan penyakit, seperti sistem pengobatan tradisional Nyerang untuk penyakit luka dan luka bakar pada masyarakat Sarolangon ( Perniwati,2019: 45), Sistem pengobatan tradisional Tetemas pada masyarakat di Pulau Temiang, sistem Pengobatan Tetemas adalah pengobatan yang digunakan untuk penangkal setan,atau gangguan mahluk halus dan bahan yang dibuat yaitu kunyit muda sebesar jari kelingking yang sudah dijampi-jampi ( Elva Yusanti, 2019:11). 
Sistem pengobatan tradisional juga dilakukan oleh komunitas adat terpencil seperti suku Mentawai di Sumatera Barat dan Suku Anak Dalam di Propinsi Jambi. Sistem pengobatan tradisional suku Mentawai, dikenal dengan sistem pengobatan Sekerei yang menggunakan daun-daunan dan ritual sebelum memberikan obat kepada pasien( Lucky Zamzami:2013:-9). Adapun Sistem Pengobatan tradisional pada Suku Anak Dalam dikenal dengan sistem pengobatan Basale dan Begijol.

Sistem pengobatan Basale dilakukan dengan ritual/upacara tertentu. Upacara Basale (Penyembuhan) merupakan ritual masyarakat Suku Anak Dalam yang bertujuan untuk menyembuhkan seseorang yang sakit akibat roh-roh jahat. Dalam adat istiadat masyarakat suku anak dalam atau Anak Rimba, terdapat banyak kegiatan upacara atau ritual yang memiliki tujuan untuk menghormati arwah nenek moyang mengharap keberkahan, dan untuk menjauhkan malapetaka (.Ahmad Akbar,2010:14), akan tetapi sistem pengobatan tradisional yang masih bertahan dimasyarakat menunjukkan bahwa Sistem pengobatan tradisonal diatas menunjukkan bahwa masyarakat masih bertumpu kepada sistem pengetahuan lokal, ini menunjukkan bahwa masyarakat mempunyai kecenderungan untuk mengurangi atau menghentikan penggunaan obat obat berbahan kimia dan menggunakan sistem pengobatan moderen dengan tenaga mendis, dan tetap mempertahankan sistem pengobatan tradisional sebagai sistem pengobatan alternatif.

Sistem Pengobatan Begijol akan menjadi fokus dari penelitian ini, dimana Fokus penelitian ini akan membahas mengapa sistem pengobatan tradisional Begijol pada Suku Anak Dalam yang berada di Desa Bungku masih mempertahankan tradisi sistem pengobatan Begijol sebagai alternatif dalam penyembuhan penyakit yang telah memeluk agama Islam dan masyarakat Desa Bungku pada umumnya. Selain itu bagaimana pandangan masyarakat Desa Bungku mengenai sistem pengobatan Tradisional Begijol.

Tulisan ini merupakan sebuah kajian etnografi yang menggunakan wawancara mendala, informan ditentukan dengan menggunakan model purposif sampling. Pembahasan artikel ini akan mendeskripsikan sistem pengobatan Begijol 


\section{THEORITICAL FRAMEWORK (نظريات)}

Sistem pengobatan tradisional sampai detik ini masih bertahan, meskipun teknologi biomedis mengalami perkembangan yang sangat pesat dan semakin mutakhir, ini menunjukkan bahwa kepedulian masyarakat terhadap sistem kesehatan menjadi fenomena yang menarik untuk dilakukan kajian. Sistem Pengobatan tradisional tidak bisa melepaskan diri dari pengetahuan budaya masyarakat lokal, karena kebudayaan merupakan keseluruhan sistem gagasan, tindakan dan hasil karya manusia dalam kehidupan masyarakat yang dijadikan milik dari manusia dengan belajar (Koenjaraningrat:1980:144) Dalam hal ini kebudayaan juga merupakan sistem nilai yang berkembang dan dipertahankan yang berbentuk tradisi di masyarakat merupakan bagain yang tidak bisa terpisahkan dari kehidupan mereka. Misalnya tradisi dalam sistem Pengobatan tradisional yang ada di masyarakat, dimana tradisi sistem pengobatan tradisional merupakan budaya warisan turun temurun. Piotr Sztompka, menejelaskan tradisi adalah keseluruhan benda material dan gagasan yang berasal dari masa lalu namun benar-benar masih ada kini, belum dihancurkan, dirusak atau dilupakan (Piotr Sztompka :2011:69-70). Sistem pengobatan tradisional terbagi menjadi dua yaitu cara penyembuhan tradisional atau traditional healing yang terdiri dari pada pijatan, kompres, dan sebagainya serta obat tradisional atau traditional drugs yaitu menggunakan bahan-bahan yang telah tersedia dari alam sebagai obat untuk menyembuhkan penyakit

Sistem Pengobatan Tradisional tentunya sangat berkaitan dengan konsep sehat dan sakit, Foster dan Anderson menjelaskan konsep penyakit masyarakat ada dua kategori. Pertama personalistik munculnya penyakit disebabkan oleh intervensi dari suatu agen yang aktif, yang dapat berupa mahkluk supranatural (mahluk gaib atau dewa), mahluk yang bukan manusia (hantu, roh, leluhur, atau roh jahat) maupun mahluk manusia ( tukang sihir, tukang tenung). Kedua Naturalistik, penyakit dijelaskan dengan istilah-istilah yang sistematik dan bukan pribadi. Naturalistik mengakui adanya model keseimbangan, sehat terjadi karena unsur-unsur yang tetap dalam tubuh seperti panas, dingin, cairan tubuh berada dalam keadaan seimbang menurut usia dan kondisi individu dalam lingkungan alamiah dan likungan sosialnya, apabila keseimbangnya terganggu, maka hasilnya adalah penyakit( Foster dan Anderson, 1986:63-67). 
Sistem pengobatan tradisional dengan kategori personalistik banyak terjadi dan terdapat pada masyarakat tradisional seperti sistem pengobatan tetamas pada masyarakat Pulau Temiang, Jambi dan sistem pengobatan sikere pada masyarakat Mentawai Sumatera Barat. Sistem Pengobatan Tradisional dengan kategori banyak dilakukan dengan menggunakan ritual atau upacara pengobatan.

Ritual merupakan salah satu bentuk pola interaksi antara manusia dengan mahluk lain, bisa itu tuhan ataupun mahluk gaib lainnya. Upacara ritual timbul karena adanya dorongan perasaan manusia untuk melakukan berbagai perbuatan yang bertujuan untuk melakukan berbagai perbuatan yang bertujuan untuk mencari hubungan engan dunia gaib. Hubungan antara manusia dengan kekuatan gaib tersebut terjadi karena kepercayaan bahwa keselamatan hidup manusia sangat tergantung kepada kekuatan gaib. Oleh karena itu, hubungan tersebut harus selalu dijaga dengan sebaikbaiknya, dan kebiasaan yang dilakukan melalui berbagai cara yang salah satunya bentuknya melalui upacara ritual yag disebut dengan Ritual mengobati penyakit berhubungan dengan kekuatan supranatural dan mempunyai suatu kesakralan(rites of healing) ( Bustanudin Agus:2006:98), bahkan tidak tertutup kemungkinan menggunakan hal hal yang bernuansa magic, menurut Frezer magic adalah segala perbuatan manusia, termasuk abtraksi-abtraksi dari perbuatan untuk mencapai suatu maksud melalui kekuatan-kekuatan yang ada dalam alam, serta seluruh kompleks anggapan yang ada dibelakangnya (Koentjaraningrat:1992:231)

\section{METHOD (طريقة \منهج البحث)}

Penelitian ini dilakukan di Desa Bungku Kecamatan Bajubang Kabupaten Batanghari Provinsi Jambi yang merupakan salah satu Desa di Kecamatan Bajubang yang dihuni atau ditempati oleh Suku Anak Dalam. Pendekatan penelitian ini menggunakan metode penelitian kualitatif yang bersifat deskriptif. (Moleong: 11) Metode penelitian deskriptif adalah suatu metode yang digunakan untuk menemukan pengetahuan terhadap subjek penelitian pada suatu saat tertentu. Serta menggunakan pendekatan etnografi yaitu sebuah kajian tentang mendeskripsikan suku-suku bangsa. Peneliti menggunakan tekhnik Snowball, Pada penelitian ini penulis menggunakan metode penelitian kualitatif (penelitian lapangan). Teknik yang digunakan penulis adalah observasi, wawancara, dan dokumentasi. 
Analisa data adalah kegitan mengatur, mengurutkan, mengelompokkan, memberi kode atau tanda, dan mengkategorikan data tersebut. Semua data yang berhasil diperoleh dari wawancara, observasi, dan dokumentasi dimasukkan dalam analisa data. Analisa data berguna untuk mereduksi data menjadi perwujudan yang dapat dipahami melalui pendeskripsian secara logis dan sitematis. Analisa data penelitian budaya berupa proses pengkajian hasil wawancara, pengamatan, dan dokumen yang telah terkumpul. Data tersebut sangat banyak jumlahnya, yang kurang relevan patut direduksi. Analisis bersifat terbuka, Open-Ended dan induktif

\section{FINDINGS \& DISCUSSION (بحث ومناقشة)}

\section{Sejarah Suku Anak Dalam}

Sejarah Suku Anak Dalam yang berada di Desa Bungku berasal dari Nenek Moyang mereka yang tinggal di Desa Bungku. Adapun untuk nenek moyang yang sampai didesa bungku memiliki kisah yang diceritakan oleh Bapak Mat Tafiz.

"Bungku dak lepas dari asal usul lorong semikat yang ado di Bungku, Markandang. Masa tu ada empat beranak yang idak ado kampung macam ni, idak katek kebun macam ni, mano nak dio tiduk, mano nak tiduk temasuk di mimpi semikat dari penukal. Kau mikat kato urang tua dalam mimpi. Kau masuk lah sako besak, ini Bungku pakek la namo kau. Ado pusako besak namo e. dalam mimpi mikat tu ado surang puteli duo beradek. Sikok Bayang Liku, sikok Bayang Lais. Bapaknyo Dipati Singgi Pratama. Kato mikat kalo macam tu mimpi urang tu, hayu kamu urang Sembilan majang, bini tembikat tu Sembilan. Dicicip simikat, dio kato pemikat mato, ado yang mutung, ado yang bungsu, ninggat tembilah, kamu urang Sembilan selamat tinggal. Aku mudik sako besak. Bini dio becakap, apo salah silih kami bang sampe abang ninggal kami, kamu tidak katek salah silih, kamu masak tidak sempurna lagi degan aku. Kato dio, si mikat. Serai dari peningkal itu dia betambat di Pinang Tinggi bedusun Belamang. Di dusun tu dio mimpi lagi bunuh 190 urang, samo si mikat tu. Sampelah satu tahun apo namo Bayan Riou ngambek tembakau Bayang Kemil. Ado urang bak kato Bayang Kemil di siko. Tembakau aku diambek orang semalam yang dak lain ialah mikat. Ado yang padek bagi taunyo. Dibagi tau nyo urang mano yang ngambeknyo oleh Mato Sebo, tembakau diambik mikat. Lalu diintipnyo dan diikatnyo tangannyo mikat, kamu akan aku bunuh, kato mikat lajulah, aku dak takut, aku dibunuh ninggal anak duo, dalam akalnyo, lepas tu kabur dio nyampe ke Desa Bungku Ko dan tinggal lah di Desa ko". (Wawancara, Mat Tafiz : 2021)

Beberapa literature yang penulis dapatkan, ada pula versi yang mengemukakan bahwa Suku Anak Dalam berasal dari 3 keturunan yaitu dari Sumatera Selatan, dari 
Minangkabau, dan Asli Keturunan Jambi yang berdomisili di daerah Sarolangun Bangko. (Dinas Kebudayaan dan Pariwisata Pemprov Jambi: 2010) Versi selanjutnya mengemukakan sejarah asal usul dari orang rimba. Mereka menyebutkan bahwa orang rimba berasal dari daerah pagaruyung, keturunan dari raja Merah Mato. Ada juga yang menyebut bahwa nenek moyang mereka adalah pelarian, yaitu usaha untuk menyelamatkan diri dengan masuk ke dalam hutan. Hal tersebut dilakukan untuk menghindari tekanan dari pihak kerajaan singosari, majapahit dan kolonial belanda.

Dari beberapa versi cerita di atas yang menyinggung tentang asal usul atau asal mulanya Suku Anak Dalam di Desa Bungku yang penulis dapatkan dilapangan, Suku Anak Dalam di Desa Bungku berasal dari Palembang. (Wawancara, Mat Tafiz : 2021) Hal ini didapatkan penulis setelah melakukan wawancara dengan Suku Anak Dalam setempat dan menganalisi keterangan keterangan yang didapatkan dari Suku Anak Dalam.

Suku Anak Dalam atau Orang Kubu adalah istilah yang dikembangkan oleh orang Terang untuk menyebut suku asli Melayu Jambi yang hidup menempati kawasan hutan pedalaman Jambi. (Saudagar, 2007:3) Hal ini senada dengan pendapat Suku Anak Dalam Di Simpang Sungai Mensio, Desa Lubuk Bedorong, Kabupaten Sarolangun, yang menyebutkan bahwa istilah Kubu itu adalah pendapat orang Terang yang artinya mondok dalam hutan. (Prihasyati : 3)

\section{Prosesi Pengobatan Begijol}

Tradisi pengobatan Begijol merupakan peninggalan warisan budaya dari nenek moyang Suku Anak Dalam. Mereka mempercayai ada kekuatan lain yang dapat menjadi penyembuh penyakit atau si sakit. Begijol berasal dari bahasa asli Suku Anak Dalam yang secara umum berarti "Bedikir". (Saudagar:24) Bedikir yang Suku Anak Dalam gunakan untuk mengobati pasien yang sedang sakit atau mereka menyebutnya si Sakit. Tradisi pengobatan Begijol telah dipraktekkan oleh nenek moyang Suku Anak Dalam apabila mereka terserang penyakit ringan maupun berat.

Tradisi Pengobatan Begijol biasanya dipimpin oleh seorang tokoh yang disegani atau yang biasa disebut sebagai dukun/datuk. Dukun/Datuk adalah salah seorang warga yang paling bersih hatinya, paling baik tingkah lakunya, paling banyak pengetahuan tentang pengobatan dan berasal dari keturunan ayah dan datuknya. Dalam kehidupan 
sehari-hari berbeda dengan yang lain, yang memiliki ciri menonjol yaitu berbicara pelan dan jelas, hormat kepada semua orang, dan berani menghadapi siapa saja yang berurusan dengannya. Tokoh ini memiliki kemampuan lebih dan mampu berkomunikasi dengan dunia ghaib atau arwah.

Suku Anak Dalam percaya adanya kekuatan Gaib atau Keramat, mereka yakin bahwa sebenarnya Alam Semesta ini ada mahluk halus yang menempati alam sekelilingnya dimana manusia tinggal. Roh nenek moyang dianggap mampu untuk mengawasi dan kehidupan dan membantu mereka dalam menyembuhkan penyakit. Penyakit itu bisa berupa sakit kepala, senggugut, sakit perut, demam dan lain sebagainya termasuk dala kategori penyakit ringan.

Pada setiap ritual selalu dibaca mantra yang bunyinya tidak jelas. Ketidak jelasan inilah yang tampaknya semakin membuat suasana magis upacara tersebut. Mantra ini diwarisi oleh Bapak atau Datuknya yang tidak boleh diajarkan dengan orang lain, terutama bagi orang selain Suku Anak Dalam atau orang Asing.

Begijol untuk penyakit ringan dilaksanakan kapan saja. Tetapi sebelumnya harus memberitahukan pada sang dukun sebagai pengobat dalam tradisi pengobatan Begijol. Seperti yang dikemukakan oleh Dukun Begijol, Bapak Tampis alias Boncel :

"kalu nak berobat tu, satu hari sebelum nak berobat datanglah, cari apo apo be yang nak dicari sesuai dengan penyakit yang dideritanyo. Apo apo yang harus di buat jadi dak kaget nak disitulah berubat nak disitulah cari bahan ubat".

Terjemahan :

Kalau akan berobat, satu hari sebelum akan berobat datanglah, cari apa-apa yang harus di cari sesuai dengan penyakit yang dideritanya. Apa apa yang harus di buat, jadi tidak kaget akan berobat hari itu dan mencari bahan obat.

Bahan yang dipakai dalam Tradisi Pengobatan Begijol berbeda untuk setiap jenis penyakitnya. Seperti yang akan penulis kemukakan dalam bentuk tabel.

\section{Tabel 1}

Bahan Bahan Pengobatan

\begin{tabular}{|l|l|l|}
\hline No & Jenis-Jenis Penyakit & Bahan-Bahan \\
\hline 1 & Adum (Pusing) & 1.Kemenyan \\
& & 2.Daun Sirih \\
& & 3.Api Dian \\
& & 4.Pinang \\
\hline 2 & Tebenyek (Menstruasi) & 1.Kemenyan \\
& & 2.Ayam Hitam \\
\hline
\end{tabular}




\begin{tabular}{|c|c|c|}
\hline & & $\begin{array}{l}\text { 3.Daun Sirih } \\
\text { 4.Umbut Padi } \\
\text { 5.Api Dian } \\
\text { 6.Kapur Sirih } \\
\text { 7.Gambir } \\
\text { 8.Buah Pinang } \\
\text { 9.Batok Kelapa }\end{array}$ \\
\hline 3 & Sakit Mata & $\begin{array}{l}\text { 1.Pandan Wangi } \\
\text { 2.Daun Sirih } \\
\text { 3.Kapur Sirih } \\
\text { 4.Kemenyan } \\
\text { 5.Kuali Besi } \\
\text { 6.Kayu Api } \\
\text { 7.Arang } \\
\text { 8.Batok Kelapa }\end{array}$ \\
\hline 4 & Keteguran & $\begin{array}{l}\text { 1.Daun Nangka } \\
\text { 2.Daun Kelapa } \\
\text { 3.Telur Ayam } \\
\text { 4.Kelapa } 10 \text { Buah } \\
\text { 5.Sirih } \\
\text { 6.Gambir } \\
\text { 7.Kemenyan }\end{array}$ \\
\hline
\end{tabular}

Tabel 2

Bahan-Bahan Setelah Berobat

\begin{tabular}{|l|l|l|}
\hline No & Jenis Penyakit & Bahan-bahan setelah berobat \\
\hline 1 & Adum (Pusing) & 1.Sirih \\
& & 2.Gambir \\
& & 3.Pinang \\
& & 4.Kapur Sirih \\
\hline 2 & Tebenyek (Menstruasi) & 1.Sirih \\
& & 2.Gambir \\
& & 3.Pinang \\
& & 4.Kapur Sirih \\
\hline 3 & Sakit Mata & 1.Sirih \\
& & 2.Gambir \\
& & 3.Pinang \\
& & 4.Kapur Sirih \\
\hline 4 & Keteguran & 1.Sirih \\
& & 2.Gambir \\
& & 3.Pinang \\
& & 4.Kapur Sirih \\
\hline
\end{tabular}


Setelah bahan bahan disiapkan sesuai penyakitnya, maka selanjutnya ada pula peralatan yang harus disiapkan dalam perlengkapan Upacara berupa :

1. Peralatan memasak padi yang akan di sahang dikuali yang besar, lalu diletakkan diatas tungku api yang menggunakan kayu bakar.

2. Lalu kemenyan dibakar didalam batok kelapa.

3. Ayam hitam tadi dipotong urat lehernya lalu dibelah 2

4. Sirih yang telah disiapkan, sengaja dibuat untuk dikunyah disertai campuran pinang dan gambir serta kapur sirih. Sirih ini dikunyah oleh si sakit.

(Semua Jenis Penyakit Akan Memperlakukan Bahan dengan cara yang sama).

Adapun fungsi dari masing-masing bahan yang dipersiapkan tadi akan peneliti paparkan sebagai berikut :

1. Kemenyan adalah salah satu bahan yang digunakan dalam Tradisi Pengobatan Bagajul. Kemenyan atau Suku Anak Dalam menyebutnya dengan nama "Menyan". Kemenyan merupakan syarat utama didalam tradisi pengobatan Begijol. Dalam pengobatan begijol, fungsi asap kemenyan sebagai penghubung dengan hal ghaib yang mereka percayai. Adapun membakar kemenyan tujuannya memanggil ruh nenek moyang, datang disebabkan oleh membakar kemenyan tersebut adalah ruhruh yang disebut syaithan atau jin-jin.

2. Ayam hitam bahan yang digunakan dalam pengobatan Begijol untuk menyalurkan penyakit yang diderita, atau untuk membuang penyakit atau untuk menggantikan tubuh si sakit. Jadi ayam hitam berfungsi sebagai penganti badan si sakit agar si sakit tidak lagi sakit dan sembuh.

3. Api berfungsi sebagai pembakar atau alat untuk memasak dan mengsanghang padi yang tadi sebagai bahan sesajian.

4. Umbut padi berfungsi sebagai pemantra halus. Umbut padi ini akan digoreng tanpa minyak dan diletakkan didalam wadah.

5. Sirih digunakan setelah pengobatan selesai. sirih tersebut akan dikunyah bersamaan dengan gambir, pinang, kapur sirih, dan nantinya sirih berfungsi sebagai obat penenang untuk si sakit.

Proses pengobatan Begijol dilakukan dengan cara membaringkan si sakit di tempat yang lapang dengan posisi terlentang. Lalu memakai peci untuk persiapan pembacaan mantra. Setelah itu, Dukun mempersiapkan segala bahan bahan yang digunakan untuk pengobatan. Lalu membakar kemenyan, setelah membakar kemenyan, si dukun membacakan matra, mantar yang bunginya tidak begitu jelas. Setelah mantra dibacakan lalu disertai pula dengan menempelkan ayam yang telah dipotong tadi ke tubuh si sakit. Lalu tubuh si sakit tadi yang sudah ditempelkan ayam hitam, dibacakan mantra kembali. Setelah itu, ayam diambil lalu ayam tadi dipindahkan ke kening si sakit dengan mematuk matukkan patuk ayam sebanyak 7 kali disertai pembacaan mantra. Setelah itu, membaca mantra kembali dan mengambil umbut padi tadi lalu di hempas hempaskan ke tubuh si sakit. Proses ini dilakukan oleh dukun pengobatan Begijol. Setelah itu pembacaan mantra. Selesai pembacaan mantra maka si sakit tadi disuruh bangun dan 
makan sirih yang sudah dibuatkan oleh si dukun dan si dukun membaca mantra kembali.

Terasa sekali suasana mistis pada saat pembacaan mantra oleh si dukun dan terasa sekali lemasnya badan setelah melakukan pengobatan padahal disini peneliti hanya sebagai pengamat bukan yang berobat.

Mantra-mantra dalam pengobatan ini hanya bisa dibaca oleh Dukun Begijol. Tetapi mantra ini dapat didengarkan. Penulis mendengarkan mantra yang dibacakan oleh Dukun Begijol dengan menggunakan rekaman dan Audio Visual. Adapun mantra yang diucapkan oleh dukun Begijol :

"Bismillahirahmanirrahim...

Menyan, bak Dak sampai tangan ...Bismillahirahmanirrahim...

Lailaha, Pusako ilang dak ilan makan mati kato mati idak mati mati kato la tadi.

Pusako Tujuh laut

Aku bagi ayam kumang

Kalau kau makan darah ada disiko

Kalau kau nak makan otak ada di siko

Kau nak makan hati ado disiko

Makan peranakan ado di siko

Makan nyawo ado di siko

Nak makan jantung ado disiko

Nak makan matonyo ado disiko

Silih badannya lailahaillah...

Lailahaillah hayyul, qayyum, Muhammad

Lalu ayam diletakkan ke badan si sakit

Tulang nak kemukun makan tulang

Hati nak kemukun makan hati

Daging nak kemukun makan daging

Darah nak kemukun makan darah

Sembuhlah manusio iko

Makanlah...minumlah...

Kato nak ilang-ilanglah

Kato nak mati matilah

Mati nak kupungut...lailahaillah

Nak makan hati kuganti hati

Nak makan jantung ku ganti jantung

Nak datang siko lah

Nak makan daging aku ganti daging

Nak makan tulang aku ganti tulang

Nak makan darah aku ganti darah

Kalu nak makan peranakan aku ganti peranakan 


\section{Lailahaq}

Kato kau kau urang berumat

Rupo kau idak urang berumat

Bedekatlah kamu diseberang puku

Lailahaq...

Jangan nak kau ulang lagi

Lepaslah manusio iko

Pegilah...pegilah

Lailahaq....

Bukan aku nak ganggu kau

Aku nak berubati urang

Lailahaq...

Mantra mantra yang dibaca oleh Dukun Begijol dilakukan dengan khusyuk. Jangan ada yang mengganggu ketenangan didalamnya dan jangan ada yang mengganggu ketika proses pembacaan mantra. Adapun observasi yang dilakukan peneliti, dalam pengobatan seharusnya tidak boleh orang dari luar Suku Anak Dalam menyaksikannya. Karena dengan menyaksikan proses pengobatan maka akan membuat rasa lemas dibadan yang melihatnya terutama berasal dari orang asing yang bukan dari Suku Anak Dalam. Pancaran aliran magic dalam pengobatan akan mengenai yang melihat. Hal itu memang benar dirasakan oleh yang bukan dari Suku Anak Dalam. Badan terasa lemas, dan tidak berdaya setelah melihat pengobatan yang dilakukan oleh Suku Anak Dalam secara langsung.

Dalam pelaksanaan pengobatan Begijol memiliki tata aturan yang tidak boleh dilakukan ketika sedang melakukan pengobatan. Apabila dilanggar maka akan terjadi kegagalan dalam pengobatan. Adapun pantangan yang tidak boleh dilakukan ialah Berpasangan atau sedang pacaran antara laki laki dan perempuan dalam menyaksikan proses pengobatan Begijol, jangan ada keributan dan jangan ada perkelahian ataupun pertengkaran.

Seperti yang dikemukakan oleh Masyarakat Suku Anak Dalam Bapak Ghofur :

"Kalu sedang berobat ni jangan nak bawa bawa orang pacaran, dak boleh, jangan buat keributan, jugo jangan nak buat pekelahian disiko".

Persoalan kesehatan dan menjaga kesehatan adalah hal yang penting di dalam ajaran Islam. Terganggunya persoalan kesehatan membuat seseorang tidak dapat berbuat maksimal dalam menjalankan kewajiban dan tugas tugas kemanusiaannya.(Kuntari, 2007:13) Penyakit yang terkandung dalam tubuh seseorang dapat

mempengaruhi organ syarat, pikiran dan perasaan. Maka dari itu penguatan tubuh sangat diperlukan dalam menunjang aktivitas keseharian seseorang. Ketika terserang sakit maka dibutuhkan pengobatan yang bisa mengatasi permasalahan tersebut.

Muncul fenomena yang cukup merisaukan kita berkaitan dengan maraknya bermunculan klinik-klinik pusat pengobatan alternatif dan pengobatan-pengobatan Dukun lainnya. Sebagian besar yang dikembangkan justru metode pengobatan yang bertentangan dengan prinsip-prinsip aqidah Islamiyah dan tauhid. Dan lebih berbahaya 
lagi karena para "penghusada" tersebut membingkai kegiatannya dengan performance (tampilan fisik) layaknya para Kyai, lengkap dengan serban dan gamisnya pada saat menyelenggarakan prak tek-praktek penyembuhan tadi sehingga sepintas membedakan mana yang Kyai dan mana yang Dukun cukup sulit pada saat ini, karena serbannya relatif mirip. Menjadi tanda tanya besar juga, jika kita lihat kemudian di daerah-daerah lainnya masih mempercayai pengobatan yang dilakukan oleh Dukun dan sebagainya. Jika dipandang dari sisi agama tentu ada tata cara pengobatan yang dilakukan oleh syariat islam. Adapun tata cara pengobatan nya seperti berguru pada syariat islam dan kitab islam yaitu Al-Quran.

Al-Qur'an adalah obat untuk jiwa yang gelisah seperti yang dijelaskan di dalam Surat: Ar-Ra'd: 28 :

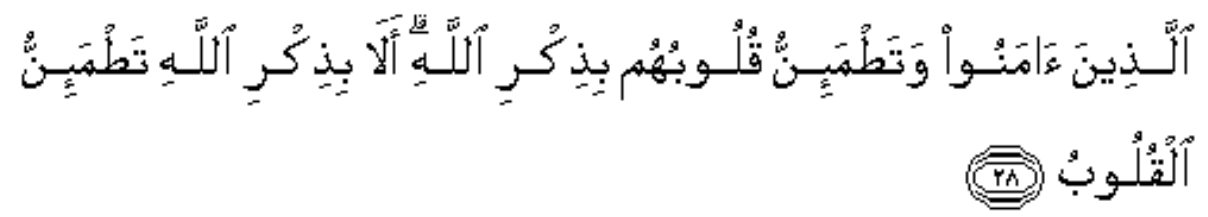

Artinya: Mereka itu orang yang beriman, yang berhati tenang karena selalu ingat kepada Allah. Ketahuilah, dengan Zikir kepada Allah, hati menjadi tenang \{QS. ArRa'd: 28 \}

Ketika kita mengalami gangguan sakit fisik maka Nabi Muhammad Saw mengajarkan kepada kita untuk berobat atau berikhtiar mengupayakan kesembuhannya. Ini adalah prinsip sunnatullah. Prinsip ini menunjukkan bahwa berobat dengan menggunakan zat-zat yang diharamkan sementara kondisinya tidak benar-benar darurat. Adapun pengobatan yang dianjurkan dalam islam ialah sebagai berikut :

1. Tidak Berobat dengan zat yang diharamkan.

Prinsip ini menunjukkan bahwa berobat dengan menggunakan zat-zat yang diharamkan sementara kondisinya tidak benar-benar darurat, maka penggunaan zat tersebut diharamkan. Misalkan pengobatan theraphy dengan meminum air seninya sendiri untuk pengobatan sakit mata, mengobati mata rabun dengan memakan kalelawar, dan mengobati gatal-gatal ditubuh dengan memakan daging kadal.

2. Berobat Kepada Ahlinya (Ilmiah).

Prinsip ini menganjurkan agar pengobatan yang dilakukan harus kepada ahlinya. Dalam ari dapat diukur. Seorang dokter dapat diukur dalam mengembangkan pengobatannya dapat diukur kebenaran metodologi nya olehdokter lainnya. Sementara seorang dukun dalam mengobati pasiennya tidak dapat diukur metode yang digunakan oleh dukun yang lain. Sistem yang tidak dapat diukur inilah yang dikatakan sebagai tidak ilmiah dan tidak metodologis.

3. Tidak menggunakan mantra atau sihir.

Hal ini harus menjadi perhatian besar dari orang-orang yang mendatangi pengobatan alternatif. Memperhatikan dengan seksama, apakah pengobatan yang dilakukannya menggunakan sihir atau tidak. Pengobatan yang menggunakan unsurunsur syirik adalah termasuk salah satu bentuk kemusyrikan. 
Pengobatan begijol merupakan tradisi pengobatan yang telah lama dilakukan oleh masyarakat baik dari keturunan Suku Anak Dalam sampai kepada masyarakat yang bukan dari Suku Anak Dalam atau orang terang. Pengobatan Begijol yang dilakukan memang jika dditelaah secara spesifik tidak sesuai dengan kaidah dan ajaran islam. Karena pengobatan Begijol ini menggunakan mantra, dan sesajian yang diercaya dapat membantu atau menjadi pelampiasan penyakit yang diderita oleh si sakit. Pengobatan Begijol yang masih dipercaya hingga saat ini tentu memiliki alasan tertentu kenapa masih bertahan ditengah zaman modern seperti sekarang ini. Masyarakat yang berobat menggunakan Begijol ini ternyata memiliki persepsi tersendiri terhadap pengobatan ini, yang menurut mereka pengobatan ini merupakan pengobatan yang cepat dalam menyembuhkan penyakit dibandingkan dengan pengobatan lainnya. Karena persepsi dan kepercayaan masyarakat terhadap pengobatan Begijol inilah yang membuat pengobatan ini tetap diminati oleh masyarakat baik di Desa Bungku maupun dari luar desa Bungku dan tetap dipertahankan hingga saat ini.

\section{A. Faktor-faktor masyarakat Suku Anak Dalam memakai pengobatan Begijol dalam sistem penyembuhan penyakit}

Ada beberapa faktor yang mempengaruhi mengapa Upacara Begijol pada Suku Anak Dalam di Desa Bungku masih sering dilaksanakan. Melalui observasi dan wawancara yang dilakukan, peneliti mendapatkan informasi bahwa ada factor internal yang melatarbelakangi pelaksanaan upacara ini masih sering dilakukan. Adapun faktor tersebut ialah :

A. Tradisi. Ttadisi pengobatan Bagajul ialah teradisi pengobatan yang dilakukan secara turun temurun, maksudnya tradisi pengobatan ini adalah warisan ari nenek moyang mereka. Adapun pernyataan ini senada dengan wawancara yang dilakukan dengan Bapak Tamfiz alias Boncel selaku Dukun Bagajul yang mengemukakan :

"Kami ko ado perobatan ko turun temurun dari nenek muyang kami, datuk kami".

Kepercayaan mereka terhadap roh-roh leluhur yang dapat menyembuhkan suatu penyakit mereka yakini dapat membantu menyembuhkan penyakit yang diderita. Sikap seperti ini mencerminkan bahwa masih kentalnya kepercayaan terhadap kekuatan magik. Magik adalah segala sistem perbuatan dan sikap manusia untuk mencapai suatu maksud engan menguasai dan mempergunakan kekuatan dan hukum hukum gaib yang ada di alam. (Akbar, 3)

B. Motivasi. Motivasi dari Komunitas Suku Anak Dalam untuk tetap mempergunakan pengobatan karena mereka menganggap pengobatan ini sangat ampuh dan sangat mujarab dalam mengobati penyakit. Seperti yang dikemukkan oleh Bapak Gofur yang merupakan Anggota Masyarakat Suku Anak Dalam.

"Sayo ko pernah cubo cubo dak pakek berubat bagajul ni, sayo pegi lah kedokter. Lah seminggu sayo dirumah sakit karenanyo kepalak sayo sakit. Dak taunyo dak jugo sembuh. Akhirnyo sayo pegi lagi berubat bagajul, nah, ditanyo apo syaratnyo, rupo rupoe minta dipotongkan kambing di kebon 
sayo. Dipotonglah dikebun dengan datuk Tamfiz tu. Lah sudah tu...duo hari sudah lepas tu sembuhlah sayo dari sakit kepalak yang dulu dulu tu”."

Mereka sangat mempercayai pengobatan ini sebagai jalan untuk penyembuhan penyakit. Faktor eksternal yang dimaksud oleh peneliti disini ialah :

1. Kekecewaan terhadap tenaga medis, kekecewaan ini menyebabkan mereka untuk beralih ke pengobatan Begijol. Hal ini senda dengan wawancara yang saya lakukan dengan masyarakat luar atau orang terang yang mengatakan :

“Suku Anak Dalam masih percaya pengobatan itu karena suku anak dalam pernah berobat ke Dokter. Tapi meninggal. Bapak Nasir Namanya. Meninggal karena dibawa kerumah sakit. Itu yang buat mereka masih mempertahankan tradisi pengobatan Begijol sampai sekarang”.

Karena kekecewaan itulah maka Suku Anak Dalam Desa bungku masih mempertahankan Tradisi Pengobatan Begijol.

2. Menjaga solidaritas sosial, sistem kekerabatan sangat kuat sehingga apabila mereka melaksanakan tradisi pengobatan Begijol maka akan sibuk dan turut serta Komunitas Suku Anak Dalam yang lainnya membantu mencari bahanbahan yang digunakan dalam perobatan.

3. Pemahaman agama yang kurang sehingga masih dilakukannya tradisi pengobatan Begijol. Suku Anak Dalam Desa Bungku Sudah diberikan pembinaan agama oleh Departemen Sosial, tetapi tingkat pemahaman mereka tentang agama masih sangat minim. Mereka memang memeluk islam tetapi belum melakukan syariat islam dengan baik. Walaupun didalam rumah mereka sudah terdapat simbol keagamaan, seperti ucapan assalamualaikum.Wr.Wb di depan rumah mereka. Ada atribut keagamaan seperti peci, sajadah dan lainnya.

Masyarakat terang yang mempercayai Tradisi Pengobatan Begijol ini pun dikarenakan setelah melakukan pengobatan ini sakit yang diderita benar-benar sembuh. Tanpa harus pergi jauh jauh ke rumah sakit. Selain itu terbatasnya pengobatan yang ada Di Desa Bungku mebuat masyarakat mempercayai Tradisi Pengobatan Begijol sebagai alternative berobat.

\section{CONCLUSIONS (خلاصة |خاتمة)}

Setelah membahas dan menguraikan permasalahan mengenai Kajian Tradisi Pengobatan Begijol di Desa Bungku Kabupaten Batanghari, maka penulis menarik benang merah sebagai berikut :

1. Pengobatan yang dilakukan oleh Suku Anak Dalam tetap bertahan hingga saat ini di tengah zaman modern dikarenakan kekecewaan Suku Anak Dalam terhadap tenaga medis yang tidak bisa mengobati penyakit yang diderita dan keyakinan akan kepercayaan bahwa Pengobatan Bagajul dapat menyembuhkan penyakit atas dasar 
telah adanya pembuktian yang dilakukan oleh kerabat, keluarga maupun orang terang dengan pengobatan Begijol ini.

2. Rendahnya tingkat keilmuan tentang Agama Islam, sehingga Suku Anak Dalam masih tetap melaksanakan pengobatan Begijol.

3. Tradisi pengobatan Bagajul merupakan suatu kegiatan ritual yang berfungsi untuk mengobati berbagaijenis penyakit seperti senggugut, sakit kepala, demam, flu, batuk dan penyakit lainnya. pengobatan ini dipercaya dapat menyembuhkan penyakit sama seperti hal nya dokter yang menyembuhkan penyakit. Dalam proses pelaksanaan tradisi bagajul ini dibutuhkan suasana yang khusyuk, tenteram, sunyi, dan keakuran sesama manusia. Apabila ada pertegkaran maka pengobatan tersebut akan gagal. Dalam hal ini pengobatan ini mengajarkan keharmonisan sesama manusia.

4. Dalam proses pelaksanaan Tradisi Pengobatan Begijol, memerlukan kerjasama antara dukun, si sakit dan kelurga lainnya untuk membantu mencari apa apa saja persyaratan yang akan dibawa pada saat pengobatan. Pihak yang sakit juga mengundang keluarga dekat dan kerabat dekat. Dalam fenomena ini mengajarkan betapa pentingnya gotong royong.

5. Pengobatan yang dilakukan didalam syariat islam tentulah tidak mempercayai halhal yang bersifat ghaib dan biasanya tidak akan baik jika mencampurkan suatu mantera dengan ayat-ayat suci al-quran. Ditambah dengan memberikan sesajian. Hal itu tidak dibenarkan dalam Ajaran Agama Islam.

\section{BIBILIOGRAPHY (قائمة المراجع)}

Agus, Bustanudin, Agama Dalam Kehidupan Manusia, Jakarta: PT Raja Grafindo Persada, 2006.

Bastomi, Suwaji, Kebudayaan Apresiasi Pendidikan Seni. FKIP: Semarang, 1986.

Endaswara, Suwardi, Metode Teori Tekhnik Penelitian Kebudayaan, Yogyakarta: Pustaka Widyatama, 2006.

Faisal, Sanapiah, Format-format Penelitian Sosial Dasar-dasar dan Aplikasi, Jakarta: Rajawali, 1992.

J, Lexy, Meleong, Metodologi Penelitian Kualitatif, Bandung: Remaja Rosdakarya, 2006.

Koenjaningrat, Beberapa Pokok Antropologi Sosial, Jakarta : Dian Rakyat, 1992.

Maulana, Nova, "Buku Ajar Sosiologi dan Antropologi Kesehatan", Nuha Medika:Yogyakarta

P, James, Spradley, Metode Etnografi, Yogyakarta: Toara Wacana, 2006.

Sztompka, Piotr, Sosiologi Perubahan Sosial, Jakarta: Prenada Media Group, 2011. 
Sarwono, S, Sosiologi Kesehatan: Beberapa Konsep serta aplikasinya, Yogyakarta: Gajah Mada Pers, 1993.

Tim penyusun buku Pedoman Skripsi, Pedoman Penulisan Skripsi Fakultas Adab Sastra dan Kebudayaan Islam, Jambi: Fakultas Adab Sastra dan Kebudayaan Islam, 2011.

Koentjaraningrat, Beberapa pokok antropologi sosial, Jakarta: Dian Rakyat, 1992.

\section{Referensi Penelitian}

Akbar, Ahmad, Upacara Basale Suku Anak Dalam Di Desa Nyogan Kecamatan Mestong Kabupaten Batanghari.

Dumatubun, A, E, E-Jurnal, Kebudayaan dan Kesehatan Orang Papua dalam perspektif antropologi kesehatan Volume 1 No.1, Agustus 2002, diakses pada 14 Agustus 2017 Pukul 16.00 Wib.

Doni, Saputra,Skripsi Sistem Pengobatan Tradisional Pada masyarakat Nagari Sikuncur Kecamatan V Koto Kampung Dalam Kabupaten Pariaman.

Dedes Kurniadi, Skripsi Tradisi Lelang dalam pernikahan di desa rantau panjang, (Jambi:Sultan Thaha Press, 2012.

http://digilib.uinsby.ac.id/311/5/Bab\%202.pdf.

Kompas, E-Published Featured News, "Tradisi Besale Suku Pedalaman Jambi”, 5 Januari 2015.

Mailinar dan Bahren Nurdin, Kehidupan Keagamaan Suku Anak Dalam di Dusun Senami III Desa Jebak Kabupaten Batanghari, dilihat pada tanggal 26 Agustus 2017 pukul $13.00 \mathrm{Wib}$.

Tambunan, Irma, dalam http://202.146.5.33/Kompas-cetak/._Judul: Tanah Air Tradisi Basale, Bertahan Bersama Suku Anak Dalam diunduh pada Sabtu Oktober 2017, akses Http://digilib.uinsby.ac.id/311/5Bab\%202.pdf

Tedi Rahman, Skripsi Sistem Pengobatan Tradisional Tasapo" Studi kasus di Nagari Sibarambang Kecamatan X Koto Diatas Kabupaten Solok, Universitas Andalas Jurusan Antropologi Sosial, diakses 13 Oktober 2017

Tini, Suryaningsih, E-Jurnal, Peranan Sando Dalam Pengobatan Tradisional Pada Masyarakat Onembute Volume 06 No 2 Tahun 2015, diakses pada 14 Oktober 2017 pukul $14.00 \mathrm{Wib}$.

Zamzami, Lucky, Sekerei Mentawai : Keseharian dan Tradisi pengetahuan local yang digerus oleh zaman, Volume 34 No 1 Januari-Juni 2013 diakses pada tanggal 16 Oktober 2017 Pukul 17.00 Wib.

Dloyanah Kusumah, Pengobatan Tradisional Orang Bugis-Makasar”, Penelitian Sejarah dan Budaya, Volume 09.No 2 Tahun 2017.

Ahmad Akbar, Skripsi Upacara Basale Suku Anak Dalam di Desa Nyogan Kecamatan Mestong Kabupaten Muaro Jambi Provinsi Jambi.

Elva Yusanti, Fungsi Mitos Dalam Kehidupan Masyarakat Pulau Temiang, Jambi, Totobuang, Volume 7 No 1, Juni 2019 hal 11 Di Unduh Pukul 09:23

Tini Suryaningsi, Peranan Sando dalam pengobatan tradisional pada masyarakat Onembute 
Lucky Zamzami, Sekerei Mentawai : Keseharian dan Tradisi pengetahuan local yang digerus oleh zaman, Antropologi Indonesia, Volume 34 No 1 Januari-Juni 2013. Piotr Sztompka, Sosiologi Perubahan Sosial.(Jakarta:Prenada Media Group, 2011.

Foster dan Anderson, Antropologi Kesehatan (Jakarta:UI Press, 1986), hal 63-6

Bustanudin Agus, Agama dalam Kehidupan Manusia, (PT Raja Grafindo Persada),2006. 